\title{
NILAI-NILAI PENDIDIKAN ISLAM \\ DALAM FILM ANIMASI UPIN DAN IPIN
}

\author{
Muhamad Jaelani \\ Sekolah Tinggi Ilmu Tarbiyah (STIT) Sirojul Falah Bogor \\ E-mail: muhamadjaelani281@gmail.com
}

\begin{abstract}
Abstrak
Pendidikan adalah hak setiap warga negara, dengan adanya pendidikan maka kualitas manusia akan semakin baik. Negara yang besar dan kaya akan sumber daya alam ini jika tidak dikelola dan dimanfaatkan secara baik oleh orang-orang yang berkompenten di dalamnya maka negara ini akan runtuh seketika. Pada masa lalu, bangsa Indonesia dikagumi oleh bangsa lain di dunia. Namun saat ini, betapa kita menyaksikan bangsa Indonesia menjadi bangsa barbarian. jika dahulu penyampaian nilai-nilai pendidikan baru berupa tulisan dan lisan, maka di era modern digunakan media yang beragam dan canggih. Salah satunya dengan film. film yang menarik audiens, khususnya anak-anak adalah Film animasi Upin dan Ipin. Film animasi yang tidak menampilkan kekerasan melainkan banyak menampilkan nilai-nilai islam, berbeda dengan film animasi yang lain yang banyak menampilkan adegan yang seharusnya tidak ditampilkan di depan anak-anak. Dan terdapat nilai-nilai pendidikan Islam dalam film Upin dan Ipin yaitu nilai pendidikan akidah, nilai pendidikan ibadah, nilai pendidikan akhlak.
\end{abstract}

Kata kunci: Nilai Pendidikan Islam, Film Upin dan Ipin, Musim II ‘Upin dan Ipin’

\begin{abstract}
Education is the right of every citizen, with education there will be better human quality. A large country and rich in natural resources if not managed and utilized properly by people who are competent in it, this country will collapse at once. In the past, the Indonesian people were admired by other nations in the world. But now, how we see the Indonesian people become barbarian. if in the past the delivery of new educational values in the form of written and oral, then in the modern era used a diverse and sophisticated media. One of them is with film. films that attract audiences, especially children, are Upin and Ipin animated films. Animated films that do not display violence but show a lot of Islamic values, are different from other animated films that feature scenes that should not be shown in front of children. And there are values of Islamic education in the film Upin and Ipin namely the value of religious education, the value of religious education, the value of moral education.
\end{abstract}

Keywords: The Value of Islamic Education, Upin and Ipin Films, Season II 'Upin and Ipin' 


\section{Pendahuluan}

Dalam penjelasan Undang-Undang Sistem Pendidikan Nasional Nomor 20 Tahun 2003 dikemukakan bahwa manusia membutuhkan pendidikan dalam kehidupannya. Pendidikan merupakan usaha agar manusia dapat mengembangkan potensi dirinya melalui proses pembelajaran dan atau cara lain yang dikenal dan diakui oleh masyarakat. ${ }^{1}$ Pendidikan sebagai sarana penyebaran nilai-nilai ajaran agama dan menjadi medium bagi terjadinya transformasi nilai dan ilmu pengetahuan yang berfungsi sebagai pencetus corak kebudayaan dan peradaban manusia.

Pendidikan Islam adalah suatu sistem pendidikan yang mencakup seluruh aspek kehidupan yang dibutuhkan oleh hamba Allah sebagaimana Islam telah menjadi pedoman bagi seluruh aspek kehidupan manusia, baik dunia maupun ukhrawi. Dalam menjalani kehidupan, agama Islam merupakan agama yang yang paling sempurna dalam ketuhanan. Agama Islam telah mengatur berbagai aspek di dalamnya. Di antara aspek tersebut meliputi hal ibadah dan muamalah, tidak terkecuali dalam aspek pendidikan. Nilai Islam dan Pendidikan Islam sebagai suatu sistem nilai, menjadi pegangan hidup bagi peserta didik. Selanjutnya menjadi rujukan dan bagian kepribadian dalam menjalani kehidupan sehari-hari.

Pendidikan Islam selain menjadi tanggung jawab pemerintah juga menjadi tanggung jawab masyarakat sebagai bagian dari negara. Pelaksanaan pendidikan Islam secara mikro sesungguhnya menjadi tanggung jawab utama dan pertama dalam lingkup keluarga adalah orangtua. Siapa dan pihak mana pun yang melaksanakan pendidikan Islam dimaksudkan untuk mencapai tujuan pendidikan sebagaimana diamanahkan oleh Allah Swt. Yaitu untuk mempertahankan dan meningkatkan fitrah keimanan yang telah dianugerahkan kepada manusia sejak dalam kandungan. ${ }^{2}$

Pakar Pendidikan, Mochtar Buchori menilai sistem Pendidikan di Indonesia saat ini telah kehilangan makna dan nilai. Menurutnya, hal itu terjadi karena pelaku pendidikan saat ini lebih mementingkan unsur skill, bukan knowledge. Padahal, yang penting adalah wisdom (kearifan) yang bertitik tolak dari nilai-nilai kemanusiaan. ${ }^{3}$

Secara universal nilai-nilai pendidikan Islam dapat ditransformasikan dalam bentuk apapun, termasuk dalam sebuah karya sastra. Banyak karya sastra yang memiliki visi ketarbiyahan. Dalam hal ini novel, kisah, atau cerita merupakan salah satu bentuk sastra yang

${ }^{1}$ Nurul Zuriah, Pendidikan Moral \& Budi Pekerti Dalam Perspektif Perubahan, Jakarta: Bumi Aksara, 2011, hlm.23.

${ }^{2}$ Rahmat Rosyadi, Pendidikan Islam Dalam Perspektif Kebijakan Pendidikan Nasional, Bogor: PT Penerbit IPB Press, 2004, hlm.2.

${ }^{3}$ Qiqi Yuliati Zakiyah dan A.Rusdiana, Pendidikan Nilai, Bandung: CV. Pustaka Setia,2014, hlm.76. 
memiliki keindahan dan kenikmatan tersendiri. Akan menyenangkan bagi anak-anak maupun orang dewasa, jika pengarang, pendongeng, dan penyimaknya sama-sama baik. ${ }^{4}$ Salah satu yang paling menjadi pusat perhatian adalah teknologi komunikasi masa yaitu televisi. Di setiap rumah pasti semua orang memiliki sebuah televisi, dan menjadi sebuah aktifitas yang sering dilakukan yaitu menonton televisi.

Televisi merupakan salah satu media dalam komunikasi massa dilihat dan didengar secara bersamaan. Televisi dikenal juga sebagai media hiburan, informasi dan juga media edukasi. Dengan berkembangnya televisi di Indonesia, maka semakin marak pula acara-acara yang menarik untuk dinikmati masyarakat. Siarannya ada yang berdasarkan realitas dan manipulasi, seperti program tayangan yang menampilkan drama yang berbentuk film. Film yang merupakan media yang begitu pas dalam memberikan informasi bagi masyarakat umum, salah satu jenis film yaitu film kartun animasi.

Film kartun animasi merupakan salah satu film yang menarik audiens,khususnya anak-anak. Anak-anak sekarang lebih cenderung menghabiskan waktunya duduk didepan televisi, menonton film kartun animasi. salah satunya adalah film Upin dan Ipin. Film animasi Upin dan Ipin tidak menampilkan adegan kekerasan, perkelahian, dan cacian. Berbeda dengan film animasi lainnya yang masih menampilkan adegan yang seharusnya tidak di lihat oleh anak-anak. Film Upin dan Ipin Sajian film yang mencerdaskan dan mencerahkan dengan disajikan secara sederhana, komunikatif, dan mendidik. Bermula dari penelitian ini maka penulis tertarik untuk melakukan penelitia Nilai-Nilai Pendidikan Islam dalam Film Animasi Upin dan Ipin. Tulisan ini bertujuan untuk menganalisis nilai-nilai pendidikan Islam terkandung dalam film animasi Upin dan Ipin.

Agar penelitian lebih fokus dan tidak memunculkan penafsiran yang luas dari pembahasan yang dimaksud, peneliti memberikan batasan masalah penelitian mencakup film animasi Upin dan Ipin musim II episode 7-12 yaitu Tadika, Anak Bulan, Adat, Tamak, Lailatul Qadr, Kisah dan Tauladan.

\section{Pembahasan}

Nilai adalah alat yang menunjukan alasan dasar bahwa "cara pelaksanaan atau keadaan akhir tertentu lebih disukai secara sosial dibandingkan cara pelaksanaan atau keadaan akhir yang berlawanan". 5 Nilai merupakan kualitas yang tidak bergantung dan tidak berubah seiring dengan perubahan zaman. Nilai menurut Milton Research dan James Bank,

\footnotetext{
${ }^{4}$ Abdul Aziz Abdul Majid, mendidik Dengan Cerita, Bandung: Remaja Rosdakarya, 2013, hlm.08.

${ }^{5}$ http://Id.m.wikipedia.org/wiki, (diakses pada 16 Februari 2020, jam 09:45)
} 
nilai adalah :

"Suatu tipe kepercayaan yang berada dalam ruang lingkup system kepercayaan yang mana seseorang bertindak atau mengkindari suatu tindakan, atau mengenal sesuatu yang pantas atau tidak pantas dikerjakan. Dari pengertian tersebut dapat dipahami bahwa nilai merupakan sifat yang melekat pada sesuatu (sistem kepercayaan) yang telah berhubungan dengan subjek yang memberi arti (yakni manusia yang meyakini)"6

Islam memandang pendidikan nilai sebagai inti dari pendidikan itu sendiri. Nilai yang dimaksud tersebut adalah akhlak, yakni nilai-nilai yang berasal dari ajaran agama Islam yang bersumberkan Al-Qur'an dan Hadis. Nabi Muhammad SAW bersabda:

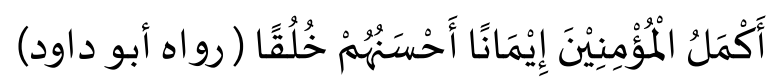

Artinya: "Orang mukmin yang paling sempurna imannya adalah yang paling baik akhlaknya.” (Riwayat Abu Dawud No. 4682 di Kitaabus Sunnah dan Tirmidzi No. 1162 di Kitaabur Radhaa')

Konsep Pendidikan Islam yang bersumber dari al-Qur'an dan al-Sunnah melahirkan berbagai teori dan sistem pendidikan yang bersifat komprehensif, integralistik, dan holistic. Pendidikan Islam bersifat komprehensif diartikan melingkupi seluruh ranah pendidikan. Pendidikan Islam bersifat integralistik diartikan tidak mengenal dikhotomi antara ilmu pengetahuan umum dan ilmu pengetahuan agama. Pendidikan Islam bersifat holistik dalam pengertian meliputi seluruh aspek kehidupan dengan prinsip pendidikan seumur hidup (life long education) yang dimulai sejak hidup dalam kandungan hingga berakhirnya kehidupan; min al-mahdi ila al-lahdi. ${ }^{7}$

Dapat disimpulkan bahwa pendidikan Islam adalah sebuah upaya terencana dalam membentuk kepribadian manusia Muslim untuk mengubah tingkah lakunya ke arah yang lebih baik atas dasar nilai-nilai ajaran Islam demi mengangkat derajat. Secara umum tujuan pendidikan Islam yaitu mendidik individu mukmin agar tunduk, bertakwa, dan beribadah dengan baik kepada Allah SWT, sehingga memperoleh kebahagiaan didunia dan di akhirat.

Sebagaimana firman Allah SWT :

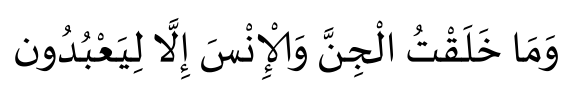

Artinya: "Dan aku tidak menciptakan jin dan manusia melainkan supaya mereka

\footnotetext{
${ }^{6}$ Eko Saputro, "Penanaman Nilai-Nilai Pendidikan Agama Islam melalui Kegiatan Cinta Alam" Mudarissa, Vol.7, No. 1, Juni 2015, hal.121.

${ }^{7}$ Rahmat Rosyadi, Pendidikan Islam Dalam Perspektif.........., Ibid, hlm. 1.
} 
mengabdi kepadaKu” (Q.S. Adz Dzariyat $/ 51: 56)^{8}$

Dalam pendidikan Islam terdapat bermacam-macam nilai Islam yang mendukung dalam pelaksanaan pendidikan bahkan menjadi suatu rangkaian atau sistem didalamnya. Nilai tersebut menjadi dasar pengembangan jiwa anak sehingga bisa memberi out put bagi pendidikan yang sesuai dengan harapan masyarakat luas. Nilai-nilai pendidikan Islam mencakup nilai pendidikan akidah (keyakinan), nilai pendidikan akhlak dan nilai pendidikan syari'ah (ibadah). ${ }^{9}$

Adapun nilai-nilai dalam pendidikan Islam yaitu:

\section{Nilai Pendidikan Akidah (keyakinan}

Kata akidah berasal dari Bahasa Arab, yaitu aqada-yaqidu, aqdan yang artinya mengumpulkan atau mengokohkan. Dari kata tersebut dibentuk kata akidah. Akidah berarti iman, kepercayaan, dan keyakinan. Akidah adalah sesuatu yang perlu dipercayai terlebih dahulu sebelum yang lainnya. Kepercayaan tersebut hendaklah bulat dan penuh, serta tidak bercampur dengan syak, keraguan maupun kesamaran. Iman merupakan kepercayaan yang tumbuhnya dari dalam hati, mengucap dengan lidah dan mengamalkannya dengan perbuatan. $^{10}$

Menurut salah satu Dosen STIT Sirojul Falah Bogor yaitu Bapak Fuad Hasan, M.A mengatakan bahwa biasanya orang yang sudah mantap akidahnya yaitu orang merasa resah terhadap keyakinannya dan timbul banyak pertanyaan dalam benak pikirannya. Dan dalam kehidupannya sering terjadi masalah terhadap keyakinanya yang membuat bingung, dan hatinya tidak tenang. Tetapi itu tanda kemantapan akidah seseorang.

Mengenai soal akidah ini bukanlah hal yang mudah, tidak sedikit orang-orang yang tergoyahkan akidahnya karena sesuatu hal yang menggiurkan. Tetapi ada juga orang yang tergoyahkan akidahnya karena suatu hidayah. Seperti halnya sahabat saya, Stevanus Hansen Mahasiswa semester akhir STIT Sirojul Falah Bogor. Beliau adalah seorang mualaf yang luar biasa perjuangannya, menurut Stevanus untuk menjadi muslim seutuhnya sangatlah sulit. Ada banyak tantangan dan juga ujian yang mungkin bagi orang yang lemah akan menyerah begitu saja, sejak dibangku sekolah menengah pertama (SMP) dia sudah di buat gelisah dan juga bingung terhadap keyakinannya. Seharusnya usia seumurnya sedang senang-senangnya bermain tanpa harus memikirkan soal keyakinan.

\footnotetext{
${ }^{8}$ https://amraini.com/tafsir-surah-adz-dzariyat-ayat-56-qs-5156/, (diakses pada 22 Februari 2020, jam 14:50)

${ }^{9}$ Qiqi Yuliati Zakiyah dan A.Rusdiana, Pendidikan Nilai, Ibid., hlm.144.

10 Aisah, Skripsi:"Nilai-Nilai Pendidikan Islam Dalam Novel Isra' Mikraj Cinta Karya Rohmat Nurhadi AlKastani”, Bogor: STIT Sirojul Falah,2017, hlm.20.
} 
Dalam keterangannya Stevanus setiap malam mendapat mimpi, namun dalam hal ini ia tidak dapat bercerita lebih dalam mengenai mimpinya. Namun sepertinya mimpi yang ada dalam tidurnya sangat luar biasa karena mendengar cerita dia setelah mimpi itu ia menangis tersedu-sedu, yang sebelumnya dia tidak pernah menangis sedalam itu. Entah apa yang ada di mimpi Stevanus Hansen, terlepas dengan mimpi itu pada akhirnya Stevanus menjadi seorang muslim walaupun harus sembunyi-sembunyi dari keluarga besarnya.

Tiap-tiap pribadi pasti memiliki kepercayaan meskipun bentuk dan pengungkapannya berbeda-beda. Pada dasarnya manusia memang membutuhkan kepercayaan, dan kepercayaan itu akan membentuk pandangan hidup dan sikap. Dalam sejarah umat manusia, akan selalu dijumpai berbagai bentuk kepercayaan. Proses pencairan kepercayaan oleh manusia tidak akan berhenti (selalu ada) selama manusia ada.

Adapun nilai-nilai pendidikan Islam Akidah dalam film animasi Upin dan Ipin pada musim ke-2 atau episode 7-12 diantaranya:

\section{a. Toleransi}

Menurut Kamus Umum Bahasa Indonesia, Toleransi yang berasal dari kata "toleran" itu sendiri berarti bersifat atau bersikap menenggang (menghargai, membiarkan, membolehkan), pendirian (pendapat, pandangan, kepercayaan, kebiasaan, dan sebagainya) yang berbeda dan atau yang bertentangan dengan pendiriannya. Toleransi juga berarti batas ukur untuk penambahan atau pengurangan yang masih diperbolehkan. Secara bahasa atau etimologi toleransi berasal dari bahasa Arab tasamuh yang artinya ampun, maaf dan lapang dada. $^{11}$

Dalam film animasi Upin dan Ipin pada episode 12 yang berjudul "Kisah dan Tauladan" dalam dialog :

Ekhsan : Hei mail... kau tak puase?

Mail : Eh..aku memang tak puase

Mei-mei : : iye lah, ia memang hari-hari makan sama saya maaa

Upin : Hei mail, tak baik kalau tak puase tak boleh makan depan orang puase kan

Mail : Iye lah, aku tak buat lagi

Dalam dialog tersebut tokoh Mail yang tidak puasa makan dihadapan orang yang berpuasa yang kemudian Upin dan Ipin menasehati mail untuk tetap menghargai orang yang berpuasa.

${ }^{11}$ Dewi Anggareni dan Siti Suhartinah, "Toleransi Antar Umat Beragama Perspektif KH. Ali Mustafa Yaqub” Jurnal Studi Al-Qur'an, Vol.14, No. 1, April 2018, hal.65. 


\section{Nilai Pendidikan Ibadah}

Ibadah merupakan terminologi Arab "Ibadah" yang berarti "menyembah dan mengabdi". ${ }^{2}$ Menurut Mahjuddin, ibadah dalam Islam itu adakalanya murni (mahdah) berupa ritualitas khusus dan rutin, adakalanya bersifat tidak murni (ghair mahdah). Ibadah mahdah adalah ibadah yang berkaitan langsung dengan hubunga Allah sebagai Tuhan-Nya dengan manusia sebagai hamba-Nya, seperti shalat, zakat, puasa, haji yang semuanya telah ditentukan waktu pelaksanaannya serta petunjuk teknisnya oleh Allah dan Rasul-Nya didalam Al-Qur'an dan hadits Nabi Saw. Adakalanya ibadah mahdah tidak dicantumkan waktunya, seperti dzikir, baca Al-Qur'an, dan bertafakkur yang termasuk dari kategori ibadah murni. Dan ibadah ghairu mahdah adalah ibadah yang berkaitan langsung manusia dengan sesamanya, dengan hewan-hewan, dan lain sebagainya. ${ }^{13}$

\section{a. Ibadah Mahdah}

1) Shalat

Menurut Imam Rafi'i shalat dari segi bahasa berarti do'a, menurut istilah syara' berarti ucapan dan pekerjaan yang dimulai dengan takbir, dan diakhiri atau ditutup dengan salam, dengan syarat-syarat tertentu. ${ }^{14}$ Kewajiban shalat dijelaskan dalam Firman Allah SWT:

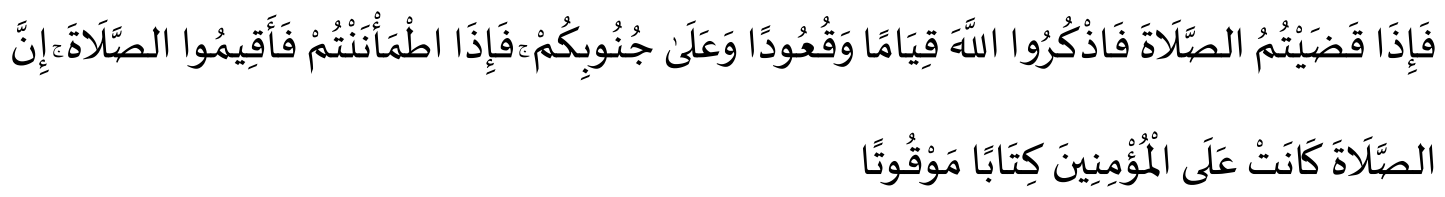

"Maka apabila kamu telah menyelesaikan shalat(mu), ingatlah Allah di waktu berdiri, di waktu duduk dan di waktu berbaring. Kemudian apabila kamu telah merasa aman, maka dirikanlah shalat itu (sebagaimana biasa). Sesungguhnya shalat itu adalah fardhu yang ditentukan waktunya atas orang-orang yang beriman." (QS.An-Nisa':103) ${ }^{15}$

Mengenai shalat dijelaskan juga dalam hadist Muttafaq Alaih/ Al Lu'lu' Wal Marjan: 6 yang artinya: “Dari Abu Thalhah bin Ubaidillah, ia berkata:”seseorang dari penduduk Najed dating kepada Nabi Saw. Sedang rambutnya terurai, dengung suaranya dari jauh terdengar tetapi tidak dimengerti apa yang ditanyakan, sampai mendekat tiba-tiba ia bertanya tentang Islam, beliau saw. Menjawab: "lima kali shalat dalam sehari semalam." Ia

\footnotetext{
${ }^{12}$ Sudarsono, "Pendidikan Ibadah Perspektif Al-Qur'an dan Hadits" Cendekia, Vol.4, No. 1, Juni 2018, hal.58.

${ }^{13}$ Ibid., hlm.59

${ }^{14}$ Abu H.F. Ramadhan B.A, "Fathul Qarib Pengantar Fiqih Imam Syafi'I”, Terj.Syekh Syamsuddin Abu Abdillah, Surabaya: Mutiara Ilmu, 2010, hlm.59.

${ }^{15}$ Abu H.F. Ramadhan B.A, "Fathul Qarib Pengantar Fiqih Imam Syafi'I”, Terj.Syekh Syamsudin Abu Abdillah, Surabaya: Mutiara Ilmu,2010, hlm.62.
} 
bertanya :"Apakah ada kewajiban shalat selain itu bagiku?" Beliau saw. Bersabda: "Tidak kecuali engkau akan shalat sunnah." Lalu beliau bersabda: "Dan puasa dibulan Ramadhan." Orang itu bertanya: "Apakah ada kewajiban puasa selain itu bagiku?” Beliau bersabda: “Tidak, kecuali engkau akan puasa sunnah." Lalu beliau menyebutkan kepadanya kewajiban zakat, maka ia bertanya: "Apakah ada kewajiban zakat selain itu bagiku?” Beliau bersabda:"Tidak kecuali engkau akan bersedekah sunnah." Maka pergilah orang itu, sambil berkata:"Demi Allah, saya tidak akan melebihi dan mengurangi dari itu.” Maka Rasulullah saw. Bersabda: "Beruntunglah jika ia benar."16

Dalam film animasi Upin dan Ipin, terdapat juga nilai pendidikan Ibadah yaitu shalat, walaupun Upin dan Ipin belum Baligh tetapi sudah mampu mengamalkan rukun Islam yang ke-2 yaitu shalat. Bukan hanya melaksanakan shalat wajib melainkan melaksanakan shalat sunah juga. Terlihat dalam adegan film Upin dan Ipin yang melaksanakan Shalat sunah tarawih dalam episode "Lailatul Qadar".

Opah yang mengasuh Upin dan Ipin juga sudah mengajarkan Upin dan Ipin dari kecil untuk melaksanakan shalat, tergambar pada episode 9 yang berjudul "Tamak":

Opah : Sudah, cepat pegih sembahyang, nanti boleh ka saran

Hal tersebut menjadi salah satu bentuk gambaran untuk para orang tua dalam mendidik anak dan juga memberikan kebiasaan yang baik terhadap nilai-nilai agama Islam dalam kehidupan sehari-hari.

\section{2) Puasa}

Shiam atau shaum adalah kata berbentuk mashdar (keduanya) menurut arti bahasa: mengekang (menahan) diri dari hal-hal yang merusak puasa, dengan niat tertentu, sepanjang siang hari, yang dapat dibuat berpuasa oleh orang Islam, berakal sehat, (bagi wanita) suci dari haid dan nifas. ${ }^{17}$ Dalam film animasi Upin dan Ipin dalam musim ke-2 ini Upin dan Ipin sudah diajarkan untuk berpuasa sehari penuh. Tergambar pada episode 11 yang berjudul "Lailatul Qadr", dalam dialog:

Upin : Wah, hebat kita ya Ipin dapat puase penuh lagi tahun ini,bukan kak Ros.

Ipin $\quad$ : Betul,betu,betul...

Dalam dialog pada film itu, Upin merasa bangga karena telah menyelesaikan puasa sebulan penuh.

\footnotetext{
${ }^{16}$ Ahmad Muhammad Yusuf, “ Ensiklopedia Tematis Ayat Al-Qur'an dan Hadits, Jakarta: Widya Cahaya, 2009, hlm.514.

${ }^{17}$ Abu H.F. Ramadhan B.A, “Fathul Qarib Pengantar Fiqih Imam Syafi I'”... Ibid, hlm.136
} 


\section{3) Membaca Al-Qur'an}

Ayat 2 pada QS: al-Zumar, Allah menjelaskan bahwa Allah menurunkan kitab suci kepada manusia sebagai bekal dan pedoman di dalam menjalani hidup yang kompleks dan berdinamika, sehingga mampu menentukan sikap dan prilakunya sesuai dengan tuntunan Allah di dalam kitab sucinya. Kitab Al-Quran itu adalah satu-satunya kitab yang memiliki keistimewaan luar biasa. maka untuk merealisasikan cita-cita Allah menciptakan manusia di muka bumi sebagai wakil dan duta dari Allah yang akan dimintai segenap pertanggung jawabannya. ${ }^{18}$ Tentunya Al-Qur'an bukan hanya saja dijadikan sebagai pajangan semata, melainkan untuk di baca dan dipahami maknanya. Hal ini tergambar pada film animasi Upin dan Ipin dalam episode 11 berjudul "Lailatul Qadar" dalam dialog:

Fizi : eh, aku ada mercon ..nanti setelah kita shalat kita maen yu?

Upin : mercon? Mana boleh maen? Nanti menganggu orang sembahyang

Ehsan : tak pe, kita maen jauh-jauh dikit

Upin : tak enaklah, aku nak baca Al-Qur'an

Dalam dialog tersebut fizi mengajak untuk bermain petasan, namun Upin menolak dan memutuskan untuk membaca Al-Qur;an pada malam itu.

\section{b. Ibadah Ghairu Mahdah}

\section{1) Bershadaqah}

Shadaqah merupakan pemberian suatu benda oleh seseorang kepada orang lain karena mengharapkan keridhaan dan pahala dari Allah Swt. dan tidak mengharapkan suatu imbalan jasa atau penggantian. Atau dapat pula diartikan memberikan sesuatu dengan maksud untuk mendapatkan pahala. Sedangkan menurut Sayyid Sabiq pada dasarnya setiap kebajikan itu adalah shadaqah. Dilihat dari pengertian tersebut, shadaqah memiliki pengertian luas, menyangkut hal yang bersifat materi atau non materi.

Dalam kehidupan sehari-hari, shadaqah sering disama-kan dengan infaq. Namun mengingat pengertian tadi dapat dibedakan bahwa shadaqah lebih umum dari pada infaq, jika infaq berkaitan dengan materi, sedangkan shadaqah materi dan non materi. Contoh shadaqah yang berupa materi seperti memberi uang kepada anak yatim setiap tanggal sepuluh bulan Muharram, sedangkan yang berupa nonmateri seperti tersenyum kepada orang lain. ${ }^{19}$ Dalam film animasi Upin dan Ipin ada dialog yang membuktika terdapat nilai pendidikan ibadah shadaqah yaitu dalam episode 9 yang berjudul adat, dengan dialog sebagai berikut:

Opah : Upin..ipin nah, antar ni kerumah atok dalng

\footnotetext{
${ }^{18}$ Sudarsono, "Pendidikan Ibadah Perspektif ......, Ibid.hlm.59

19 Qurratul Uyyun, "Zakat, Infaq,Shadaqah dan Wakaf Sebagai Konfigurasi Filantropi Islam", Islamuna, Vol.2, No. 2, Desember 2015, hal.221.
} 
Upin : Hah..tuk ape?

Ipim : Heeh, cukup kah makanan? Opah masak banyak kah?

Opah : Cukup, bulan puase nilah elok bersedekah, inikan adat kite...

Upin : Hmmm....iyelahopah..

Opah : Cepat pegi,nanti lambat nak berbuka.

Dalam dialog tersebut Upin dan Ipin diminta untuk mengantarkan makanan untuk Tok Dalang, namun Upin dan Ipin malah bertanya kepada Opah mengapa harus mengantarkan makanan tersebut kepada Tok Dalang. Secara spontah Opah memberikan pemahaman kepada Upin da Ipin bahwa itu sebagian dari ajaran agama untuk selalu bersedekah.

\section{2) Menebarkan Salam}

Secara terminologi kata salam berasal dari bahasa Arab artinya salam sejahtera, damai, salam hormat seperti sampaikan salam saya kepadanya. Pengertian salam dalam alQur'an bermakna keselamatan atau jalan keselamatan, juga dimaknai perdamaian, menyerah diri dan tunduk, yang terbanyak di antaranya bermakna mengucapkan salam keselamatan. ${ }^{20}$ Setiap agama memiliki salam yang berbeda - beda dan makna tersendiri, karena salam merupakan simbol suatu agama. Jika kita berpergian atau disekitar lingkungan kita, banyak sekali orang yang menyalah gunakan dengan meminta-minta mengharap balas kasihan yang diawali dengan kata salam. Sehingga banyak orang berpandangan kata salam hanya digunakan untuk orang kalangan bawah yang meminta-minta belas kasihan.

Anak muda dikalangan millennial juga lebih senang menggunakan kata "Hello" atau dengan bahasa gaul seperti "Hello Guys" di banding kata salam, Miris,tetapi inilah realita sekarang. Salam yang seharusnya bernilai tinggi tetapi seakan bernilai rendah bahkan tidak bernilai, menandakan nilai-nilai Islam sudah pudar dalam kehidupan. Padahal, Islam sudah mengajarkan bahwa menjawab salam hukumnya wajib dan mengucapkan salam itu sunnah. Selanjutnya Allah memerintahkan dalam firman-Nya "Apabila kamu dihormati dengan suatu penghormatan maka balaslah penghormatan itu dengan yang lebih baik atau balaslah dengan yang serupa sesungguhnya Allah memperhitungkan segala sesuatu” Q.S. an-Nisaa', 4: 86). Hamka menjelaskan membalas hormat dengan yang lebih baik artinya kalau orang mengucapkan "Assalamu'alaikum" balaslah dengan "Wa'alaikumus Salam wa Rahmatullah". Dan kalau salam itu ditambahkan lagi dengan "Warahmatullah" balaslah dengan tambahan lagi “Wabarakatuh". ${ }^{21}$ Dalam film animasi Upin dan Ipin terdapat nilai pendidikan ibadah yaitu menebarkan salam pada episode 9 yang berjudul "Adat" dalam

\footnotetext{
${ }^{20}$ Syahrudin Nasution dan Khoirudin Nasution, “Mengkaji Nilai Salam Dalam Al-Qur'an (Kajian Tafsir Tematik)”, Jurnal Ushuludin, Vol.25, No.1, Januari-Juni 2017, hlm.58.

${ }^{21}$ Ibid.hlm.67.
} 
dialog :

Upin \& Ipin : Assalamu'alaikum....Ato..oh...Atooo

Atok Dalang : :Waalaikumussalam naah nak orang mau apa ni?

Dalam dialog film tersebut Upin dan Ipin yang mengunjungi rumah Atok Dalang untuk memberikan makanan untuk berbuka puasa yang diperintahkan oleh Opahnya, sebelum masuk kedalam rumah Atok Dalang Upin dan Ipin mengucapkan salam terlebih dahulu. Yang kemudian salam tersebut dijawab oleh Atok Dalang.

\section{3) Ganjaran}

Di antara metode pendidikan dalam islam adalah metode pemberian ganjaran dan hukuman. Pemberian ganjaran dan hukuman adalah sesuatu yang disyariatkan dan termasuk salah satu sarana pendidikan yang berhasil yang sesekali mungkin diperlukan pendidik. Ganjaran dan hukuman dalam pendidikan berfungsi sebagai alat pendorong untuk meningkatkan belajar anak didik. Ganjaran sebagai imbalan dari perbuatan baik, sedangkan hukuman merupakan imbalan dari perbuatan yang tidak baik. Dalam Al-Qur'an disebutkan yang Artinya: "Barangsiapa yang mengerjakan kebaikan seberat dzarrahpun, niscaya dia akan melihat (balasan)nya. Dan barangsiapa yang mengerjakan kejahatan sebesar dzarrahpun, niscaya Dia akan melihat (balasan)nya pula. (QS. al-Zalzalah : 7-8). ${ }^{22}$ dan Ipin terdapat juga nilai pendidikan ibadah yaitu ganjaran, di episode 7 yang berjudul "Tadika" dalam dialog:

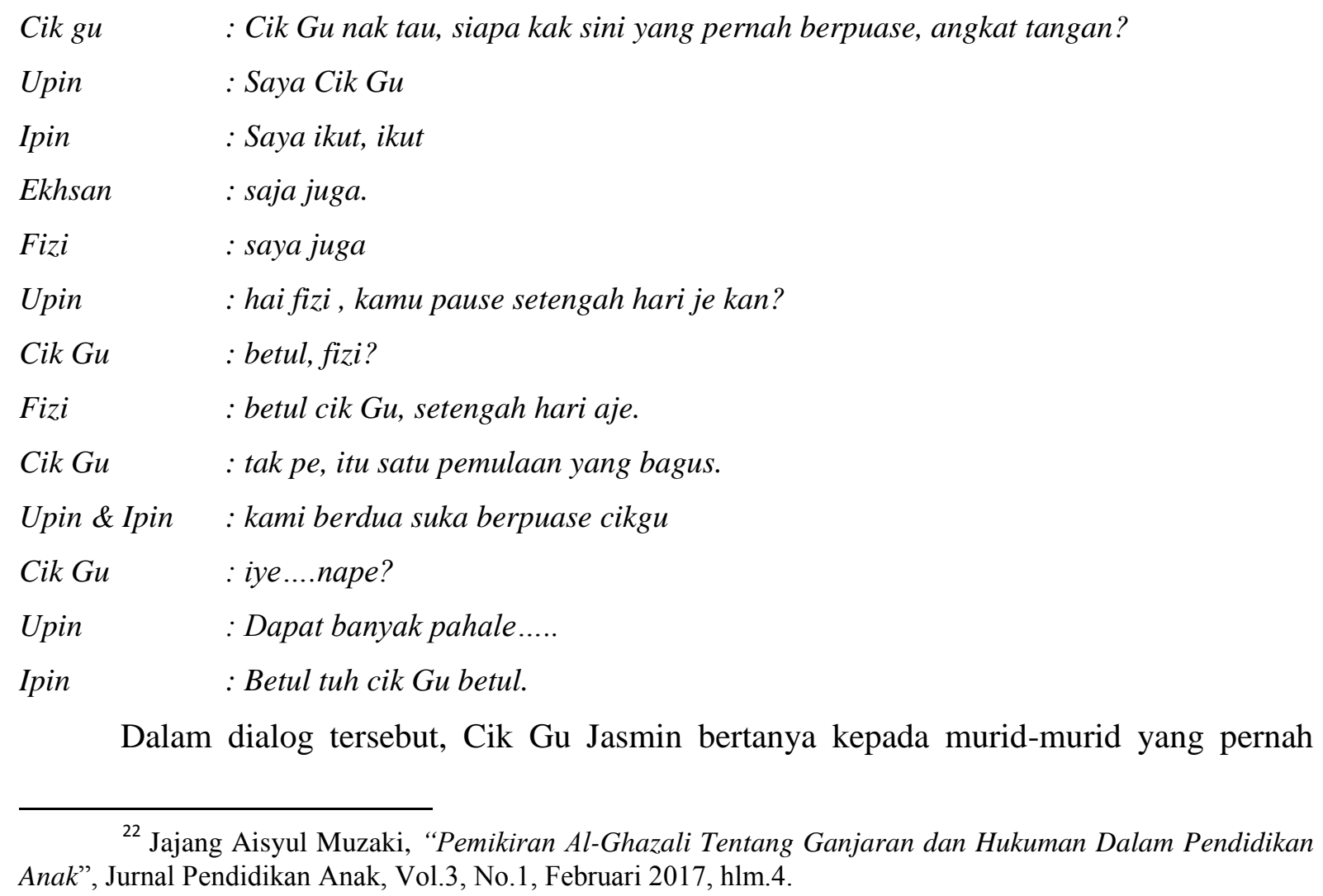


berpuasa, kemudian beberapa anak-anak mengangkat tangan. Salah satunya Fizi, namun Upin mengetahui kalau Fizi hanya berpuasa setengah hari saja. Lalu Cik Gu Jasmin mengklarifikasi hal tersebut dan Fizi membenarkan hal itu. Namun Cik Gu Jasmin tidak memarahinya ataupun mengecilkannya didepan peserta didik yang lain, melainkan Cik Gu Jasmin memberikan penghargaan sekaligus pujian. Ini merupakan suatu contoh untuk para tenaga pendidik maupun para orang tua dalam mendidik anak ataupun peserta didik.

\section{Nilai Pendidikan Akhlak}

Konsep Akhlak menurut Al-Ghazali adalah sifat yg tertanam dalam jiwa seseorang, darinya lahir perbuatan yang mudah tanpa pertimbangan pikiran terlebih dahulu. Akhlak meliputi jangkauan yang sangat luas dalam segala aspek kehidupan. Akhlak meliputi hubungan hamba dengan Tuhannya (vertikal) dalam bentuk ritual keagamaan dan berbentuk pergaulan sesama manusia (horizontal) dan juga sifat serta sikap yang terpantul terhadap semu a makhluk (alam semesta). ${ }^{23}$ Dalam film animasi Upin dan Ipin terdapat nilai pendidikan akhlak diantaranya sebagai berikut:

\section{Akhlak Kepada Allah SWT.}

Menurut Abuddin Nata, sekurang-kurangnya ada empat alasan mengapa manusia harus berakhlak kepada Allah SWT. Pertama, Karena Allah lah yang telah menciptakan manusia, dia menciptakan manusia dari air yang ditumpahkan keluar dari antara tulang punggung dan tulang rusuk. Kedua, Karena Allah lah yang telah memberikan perlengkapan pancaindera, berupa pendengaran, penglihatan, akal pikiran dan hati sanubari, disamping anggota badan yang kokoh dan sempurna kepada manusia. Ketiga, Karena Allah yang telah menyediakan berbagai bahan dan sarana yang diperlukan bagi kelangsungan hidup manusia, seperti bahan makanan yang berasal dari tumbuhan, air, udara, binatang ternak dan sebagainya. Keempat, Karena Allah yang telah memuliakan manusia dengan diberikannya akan kemampuan menguasai daratan dan lautan. ${ }^{24}$

Dalam film animasi Upin dan Ipin nilai terdapat akhlak kepada Allah salah satunya adalah :

\section{a) Beriman dan bertaqwa}

Beriman itu mempercayai dalam hati dengan sungguh-sungguh memahami wujudNya, kesempurnaan, keagungan, keperkasaan, nama-nama dan sifat-sifat-Nya, kemudian iman itu terimplementasikan dalam perbuatan dan semua aktivitas, sikap dan tindakannya

\footnotetext{
${ }^{23}$ Iwan, "Pendidikan Akhlak Terpuji Mempersiapkan Generasi Muda Berkarakter", Jurnal Al Tarbawi Al Haditsah, Vol.1, No.1, hlm.1.

${ }^{24}$ Supriyatin,"Akhlak Tasaswuf” Tasik Malaya: Latifah Pers, 2016. hlm.34
} 
dengan memelihara dan melaksanakan hak-hak Nya yang absolute, yakni memahaesakanNya. ${ }^{25}$

Disamping akhlak yang tertinggi kepada Allah beriman kepada-Nya, juga bertaqwa kepada-Nya. Sebab iman dituntut untuk diaplikasikan, cara mengaplikasikannya mesti dengan cara takwa. Takwa yang dituntut bagi orang beriman itu adalah takwa yang sebenarbenarnya takwa, tidak separuh takwa, akan tetapi ketakwaannya itu harus dengan menyeluruh, konsekuen, dan istiqamah. ${ }^{26}$

Dalam film Upin dan Ipin pada episode 9 yang berjudul "Tamak" dalam dialog sebagai berikut:

Opah : Sudah, cepat pegih sembahyang, nanti boleh ka saran

Dalam hal itu Opah Menyuruh Upin dan Ipin untuk segera melaksanakan shalat, shalat merupakan salah satu bentuk takwa kepada Allah SWT. Karena pada hakikatnya takwa itu adalah menjalankansegala perintah-Nya dan menjauhi segala larangan-Nya.dan shalat merupakan salah satuperintah Allah SWT.

Bukan hanya melaksanakan shalat upin dan ipin juga berpuasa 1 bulan penuh, hal ini tergambar dalam film animasi Upin dan Ipin episode 11 yang berjudul "Lailatul Qadr" dalam dialog sebagai berikut :

Upin : Wah, hebat kita ya Ipin dapat puase penuh lagi tahun ini,bukan kak Ros.

Ipin $\quad$ : Betul,betu,betul...

Dengan Upin dan Ipin melaksanakan Shalat dan Puasa ini menujukan bahwa dalam fim animasi Upin dan Ipin terdapat nilai pendidikan akhlak kepada Allah SWT. Memang sulit diukur keimanan dan ketakwaan seseorang akan tetapi dalam sebuah teori dalam buku Akhlak Tasawuf yang ditulis oleh salah satu dosen sekaligus Kaprodi Fakultas Tarbiyah Jurusan Pendidikan Agama Islam (PAI) STIT Sirojul Falah Bogor yaitu Bapak Supriyatin, M.Ag, beliau menuliskan "orang mukmin mesti berupaya, agar ketakwaanya itu lekat pada jiwanya dan teraplikasikan dalam perbuatannya".

Ini menunjukan bahwa film animasi Upin dan Ipin , pada tokoh Upin dan Ipin yang berpuasa dan juga melaksanakan shalat merupakan bentuk upaya untuk menjadi orang yang beriman dan bertakwa kepada Allah SWT.

\section{b) Istiqamah}

Teguh pada pendirian semula merupakan sikap istiqamah. Istiqamah suatu keadaan dan daya upaya untuk tetap tetap teguh mengkuti syariat mengharapkan ridha yang diiringi

\footnotetext{
${ }^{25}$ Ibid, hlm.35

${ }^{26}$ Ibid, hlm.38.
} 
dengan sikap berharap kepada Allah. ${ }^{27}$ Manusia yang selalu megakui, bahwa Tuhan-Nya adalah Allah, Islam itu agamanya, Muhammad itu sebagai Nabi dan Rasul-Nya. Pengakuan ini diikrarkan dengan hati, kemudian istiqamah dan berpegang teguh kepada-Nya. Inilah istiqamah yang harus termaktub dalam hati dan teraplikasi dalam perbuatan. Allah akan menurunkan malaikat dan mengilhamkan ke dalam hati dan pikirannya untuk tidak merasa takut, tidak merasa sedih. Bagi orang yang istiqamah ini akan disediakan tempatnya surga. Orang yang selalu beristiqamah, muncul motivasi keberanian, tidak merasa gentar dan takut, dan tidak pernah merasa sedih, tidak ada rasa pesimis karena hati dan pikirannya dipenuhi rasa percaya diri. ${ }^{28}$ Dalam film animasi Upin dan Ipin, tokoh Upin dan Ipin telah menunjukan sikap istiqamah yaitu dengan cara berpuasa selama satu bulan penuh dan menajalankan ibadah shalat. Dan tergambar juga dalam episode 11 yang berjudul "Lailatul Qadar", dalam dialog:

Fizi : eh, aku ada mercon ..nanti setelah kita shalat kita maen yu?

Upin : mercon? Mana boleh maen? Nanti menganggu orang sembahyang

Ehsan : tak pe, kita maen jauh-jauh dikit

Upin : tak enaklah, aku nak baca Al-Qur'an

Dalam dialog diatas Upin dan Ipin yang ajak untuk bermain petasan, tetapi Upin dan Ipin secara tegas menolaknya dan lebih memilih untuk membaca Al-Qur'an. Ini menunjukan sikap istiqamah Upin dan Ipin dalam menjalankan perintah Allah dan menjauhi laranganNya.

\section{Akhlak Terhadap Diri Sendiri}

Bagaimana seseorang bersikap dan berbuat yang terbaikuntuk dirinya terlebih dahulu, karena dari sinilah seseorang akan menentukan sikap dan perbuatannya yang terbaik untuk orang lain, sebagaimana sudah dipesankan nabi bahwa: mulailah sesuatu itu dari diri sendiri (ibda' binafsih). Begitu juga ayat Al-Qur'an telah memerintahkan untuk memperhatikan diri terlebih dahulu baru orang lain. ${ }^{29}$ Dalam film animasi Upin dan Ipin terdapat nilai pendidikan Akhlak terhadap diri sendiri diantaranya :

\section{a) Sabar}

Menurut penuturan Abu Thalib Al-Makky, sabar adalah menahan diri dari dorongan hawa nafsu demi menggapai keridhaan Tuhannya dan menggantinya dengan sungguhsungguh menjalani cobaan-cobaan Allah SWT terhadapnya. Sabar dapat didefinisikan pula dengan tahan menderita dan menerima cobaan dengan hati ridha serta menyerahkan diri

\footnotetext{
${ }^{27}$ Ibid., hlm. 50.

${ }^{28}$ Ibid., hlm. 51.

${ }^{29}$ Ibid., hlm.59.
} 
kepada Allah SWT setelah berusaha. Sabar terbagi menjadi tiga, yaitu: sabar dari perbuatan maksiat, sabar dalam menjalankan ibadah kepada Allah SWT dan sabar dalam menghadapi cobaan/musibah dari Allah SWT.

Upin dan Ipin tokoh utama dalam film animasi Upin dan Ipin memiliki karakter anak kecil yang selalu banyak tingkah, ada saja sesuatu yang dilakukannya. Tetapi, dari tingkah yang dilakukannya pasti ada pelajaran yang dapat diambil untuk penonton setianya. Dari tingkah laku Upin dan Ipin ini, Opah dan Kak Ros yang merupakan nenek dan kakak Upin dan Ipin yang tinggal serumah dengan Upin dan Ipin tentunya pernah kesal dan juga marah dengan tokoh Upin dan Ipin. Namun, tokoh Opah dan Kak Ros menunjukan sikap sayang mereka kepada Upin dan Ipin. Kasih sayang itu tidak hanya dengan kelembutan melainkan dengan peringatan juga supaya sesuatu hal yang salah dapat diluruskan dan tidak diulangi lagi.

Ini menggambarkan bahwa film animasi Upin dan Ipin terdapat nilai pendidikan Islam yaitu sabar. Yang dapat dijadikan contoh untuk para orang tua dan para pendidik, ataupun penonton setia Upin dan Ipin.

\section{b) Menunaikan Amanah}

Amanah menurut bahasa berarti kesetiaan, ketulusan hati, kepercayaan, (tsiqat), atau kejujuran. Amanah merupakan kebalikan dari sikap khianat. Amanah adalah suatu sifat dan sikap pribadi yang setia, tulus hati, dan jujur dalam melaksanakan sesuatu yang dipercayakan kepadanya, berupa harta benda, rahasia, ataupun tugas kewajiban. Pelaksanaan amanah dengan baik bisa disebut al-amin yang berarti dapat dipercaya, jujur, setia, dan aman. Amir ibn Muhammad Al-Madary pernah bertutur, "Barang siapa yang menyempurnakan dirinya dengan sifat amanat, maka ia telah menyempurnakan keberagamaannya, dan barang siapa yang menafikan sifat amanah pada dirinya, berarti ia telah membuang keberagamaannya secara keseluruhan." 30 Mencari orang pintar atau cerdas itu banyak, akan tetapi mencari orang yang menjaga kepercayaan itu sulit. Terjadi di bangsa yang besar ini, yaitu bangsa Indonesia. Wakil rakyat yang diberi kepercayaan oleh masyarakat, kini sudah yang mendustakan kepercayaan itu hanya untuk kepentingannya sendiri. Begitu miris negeri ini akan kejadian seperti itu. Nilai-nilai Islam dalam kehidupan seakan sirna dimakan zaman.

Tetapi tidak dengan Upin dan Ipin dalam film animasi Upin dan Ipin dala episode 9 yang berjudul "Adat" dalam dialog :

Opah : Upin..ipin nah, antar ni kerumah atok dalng

Upin :Hah..tuk ape?

\footnotetext{
${ }^{30}$ Ibid., hlm. 6.
} 
Ipin $\quad$ : Heeh, cukup kah makanan? Opah masak banyak kah?

Opah $\quad$ : Cukup, bulan puase nilah elok bersedekah, inikan adat kite...

Upin $\quad$ : Hmmm ....iyelah opah..

Opah $\quad$ : Cepat pegi,nanti lambat nak berbuka.

(lalu Upin dan Ipin langsung menuju rumah Atok Dalang dan sesampainya disana..)

Upin \& Ipin : Assalamu'alaikum....Ato..oh...Atooo

Atok Dalang : Waalaikumussalam, naah nak orang mau apa ni?

Upin $\quad$ : Nih Atoo, Opah bagi makanan untuk berbuka puase.

Dalam dialog pada film animasi Upin dan Ipin tersebut, Upin dan Ipin diminta untuk mengantarkan makanan oleh Opah untuk Atok Dalang. Kemudian Upin dan Ipin sebelum berangkat bertanya terlebih dahulu, setelah diberi pemahaman oleh Opah. Langsung lah Upin mengantarkan makanan ke rumah Atok Dalang, setelah dari rumah Atok Dalang Upin dan Ipin membawa kembali rantang yang awal dikasih Opah. Sesampainya dirumah, Upin dan Ipin menyerahkan kembali rantang tersebut kepada Opah. Ini menunjukan Upin dan Ipin menunaikan amanah yang diberikan oleh Opah.

\section{C) Benar dan Jujur}

Maksud akhlak terpuji ini adalah berlaku benar dan jujur, baik dalam perkataan maupun dalam perbuatan. Benar dalam perkataan adalah mengatakan keadaan yang sebenarnya, tidak mengada-ada, dan tidak pula menyembunyikannya. Lain halnya apabila yang disembunyikannya itu bersifat rahasia atau karena menjaga nama baik seseorang. Sedangkan benar dalam perbuatan adalah mengerjakan sesuatu sesuai dengan petunjuk agama. Apa yang dikerjakan menurut perintah agama, berarti itu benar. Dan apa yang tidak boleh dikerjakan sesuai dengan larangan agama, berarti itu tidak benar. ${ }^{31}$

Hal ini tergambar dalma film animasi Upin dan Ipin episode 9 yang berjudul "Adat" dalam dialog :

Upin : Opah..opah..lekas sekolah tadi ramai kawan-kawan yang tak puase opah, die orang bawa berkat, tergugat iman Ipin.

Ipin : ehh..tak adeu..tak adeu..

Kak Ros $\quad$ : Habis itu kau minum tak?

Upin $\quad$ : ehh.. tak..Upin tengok aje, iman Upin kuat.

Opah : mmm tak ape, die orang semua tak biase lagi, lainah cucu opah, kan dah puase.

Upin dan Ipin yang menceritakan teman-temannya yang tidak puasa kemudian Upin dan Ipin berbicara sesuai dengan keadaan bahwa Upin dan Ipin masih berpuasa ditengah teman-temannya tidak berpuasa.

\footnotetext{
${ }^{31}$ Ibid.
} 


\section{D) Menepati Janji (al-wafa')}

Dalam Islam, janji merupakan utang. Utang harus dibayar (ditepati).Apabila kita mengadakan suatu perjanjian pada hari tertentu, kita harus menunaikannya pada waktunya. Janji mengandung tanggung jawab. Apabila janji tersebut tidak kita penuhi atau tidak kita tunaikan, dalam pandangan Allah SWT, kita termasuk orang yang berdosa. Adapun dalam pandangan manusia, mungkin kita tidak dipercaya lagi, dianggap remeh, dan sebagainya. Akhirnya, kita merasa canggung bergaul, merasa rendah diri, jiwa gelisah, dan tidak senang. ${ }^{32}$

Dalam film animasi Upin dan Ipin dalam episode 11 yang berjudul "Lailatul Qadar" dengan dialog :
Kak Ros $\quad$ : hmmm cepat, nanti Kak Ros lambat
Upin : : iye lambat, ini semua Kak Ros punya pasal
Ipin $\quad$ : Betul tuh, Kak Ros tipu kite, mane ade anak bulan

Kak Ros : : heheh, iyelah yelah, Kak Ros minta maaf, hah puasa nanti Kak Ros janji Kak Ros bawa kalian orang ke pasar ramadhan, Boleh?

Upin \& Ipin : : hmmmmm

Kak Ros : : Akak belanje ape saje ade-ade akak nak, aka belikan

Upin : : hah, janji kak, janji,janji?

KakRos : janji

Upin : yelah kami maafkan Kak Ros

Upin \& Ipin : yeaaaa

(kemudian keesokan harinya kak Ros mengajak Upin dan Ipin ke pasar ramadhan)

Dalam dialog tersebut Kak Ros yang berjanji kepada adiknya yaitu Upin dan Ipin kemudian melaksanakan janjinya tersebut.

\section{Akhlak Kepada Keluarga}

\section{a) Berbakti kepada orangtua}

Berikutnya Anwar menjelaskan salah satu keutamaan berbuat baik kepada kedua orang tua, disamping melakukan ketaatan atas perintah Allah SWT adalah menghapus dosadosa besar. Hal itu sebagaimana tergambar dalam ucapan Ali bin Abi Thalib. Demikian pula yang dikatakan Ibn Abd Al-Barr dari Al-Makhlul. Ibnu Al-Jauzi secara terperinci menjelaskan keutamaan berbuat baik kepada kedua orang tua dalam kitabnya Birr AlWalidain. ${ }^{33}$

Dalam film animasi Upin dan Ipin, Upin dan Ipin sudah tidak mempunya kedua Orang Tua. Mereka hanya mempunyai Opah dan Kak Ros yang merawat mereka dari kecil.

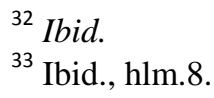


Mereka sudah ditinggalkan kedua orang tuanya sejak masih kecil. Tetapi Upin dan Ipin menganggap Kak Ros dan Opah sebagai Orang Tua mereka.

Kasih sayang Opah dan Kak Ros membuat Upin dan Ipin berbakti dan sayang kepada Kak Ros Opah juga. Walalupun karakter Upin dan Ipin ini banyak tingkah namun apabila di nasehati Upin dan Ipin selalu mendengarkannya. Dan segala sesuatu yang diperintahkan Kak Ros dan Opah, Upin dan Ipin selalu mengerjakannya. Ini bukti bahwa Upin dan Ipin berbakti kepada Kak Ros dan Opah. Walalupun mereka sudah tidak mempunyai kedua Orang Tua tapi mereka mempunyai Kak Ros dan juga Opah yang sudah mereka anggap Orang Tua mereka sendiri.

\section{b) Bersikap Baik Kepada Saudara}

Agama Islam memerintahkan untuk berbuat baik kepada sanak saudara atau kaum kerabat sesudah menunaikan kewajiban kepada Allah SWT dan ibu bapak. Hidup rukun dan damai dengan saudara dapat tercapai apabila hubungan yang terjalin dengan saling pengertian dan tolong menolong. Pertalian kerabat itu dimulai dari yang lebih dekat dengan menurut tertibnya sampai kepada yang lebih jauh. Kita wajib membantu mereka, apabila mereka dalam kesukaran. Sebab dalam hidup ini, hampir semua orang mengalami berbagai kesukaran dan kegoncangan jiwa. Apabila mereka memerlukan pertolongan yang bersifat benda, bantulah dengan benda. Apabila mereka mengalami kegoncangan jiwa atau kegelisahan, cobalah menghibur atau menasehatinya. Sebab bantuan itu tidak hanya berwujud uang (benda), tetapi juga bantuan moril. Kadang-kadang bantuan moril lebih besar atinya daripada bantuan materi. ${ }^{34}$

Dalam film animasi Upin dan Ipin, Upin selalu berbuat baik kepada Ipin dan begitupun sebaliknya Ipin selalu berbuat baik Upin. Mereka saundara kandung yang terlahir kembar dan mereka saling menyayangi satu sama lain. Mereka juga sangat sayang kepada Ka Ros, begitupun dengan Kak Ros menyayangi Upin dan Ipin. Keluarga yag hidup sederhana dengan segala kebaikan.

\section{Berbuat baik terhadap Masyarakat}

\section{a) Berbuat baik kepada tetangga}

Dianalisa oleh Anwar bahwa para ulama membagi tetangga menjadi tiga macam. Pertama, tetangga muslim yang masih mempunyai hubungan kekeluargaan. Tetangga semacam ini mempunyai tiga hak. Yaitu sebagai tetangga, hak Islam, dan hak kekerabatan. Kedua, tetangga muslim saja, tetapi bukan kerabat. Tetangga semacam ini mempunyai dua

\footnotetext{
${ }^{34}$ Ibid., hlm. 9.
} 
hak, yaitu sebagai tetangga dan hak Islam. Ketiga, tetangga kafir walaupun kerabat. Tetangga semacam ini hanya mempunyai satu hak, yaitu hak tetangga saja. ${ }^{35}$

Dalam film animasi Upin dan Ipin, terdapat nilai pendidikan Islam berbuat baik kepada tetangga, terbukti pada episode 9 yang berjudul "Adat" dimana, Opah memberikan makanan kepada Tok Dalang.

\section{Kontribusi Film Animasi Upin Dan Ipin terhadap Pembelajaran}

Dalam teknologi yang semakin maju dan juga terus berkembang, film sering kali dijadikan sebagai media pembelajaran. Karena belajar pada hakikatnya bisa didapat dari mana saja, tidak terbatas oleh ruang dan waktu. Tetapi kita harus pandai memilah dan juga memilih film yang layak dan juga bermanfaat, tidak hanya sekedar tontonan melainkan juga memberikan tuntunan.

Dalam film Animasi Upin dan Ipin, terdapat banyak sekali nilai pendidikan Islam bahkan bukan hanya itu saja nilai pendidikan karakter juga sangat kental. hal ini menunjukan bahwa film animasi Upin dan Ipin bukan hanya sekedar menyajikan tontonan melainkan sebuah tuntunan yang sangat positif bagi penontonnya. Bukan hanya untuk anak-anak saja, bahkan untuk orang dewasa dan lansia sekalipun.

Dari cerita-cerita yang disajikan, film Upin dan Ipin sangat bagus untuk dunia pendidikan bukan hanya untuk peserta didik melainkan untuk pendidiknya juga. Hal ini bisa dilihat dari setiap episode yang ditanyangkan film Upin dan Ipin selalu konsisten memberikan pesan moral. Dan dari sini bisa dikatakan bahwa film animasi Upin dan Ipin memberikan kostribusi yang besar dalam pembelajaran, dari sebuah tontonan akan berwujud menjadi tuntunan. Mata melihat setiap adegan yang ditanyangkan, telinga mendengar setiap perkataan yang di ucapkan dalam adegan, kemudian otak merespon dan berujung kepada aplikasi dalam kehidupan.

\section{Simpulan}

Dalam film animasi Upin dan Ipin musim ke II yang terdiri dari 6 episode, yaitu : Tadika, Anak Bulan, Adat, Tamak, Lailatul Qadr, Kisah dan Tauladan.mengandung nilainilai Pendidikan Islam, di antaranya: Nilai Pendidikan Akidah, yang meliputi sikap toleransi; Nilai Pendidikan Ibadah, , yang meliputi Ibadah mahdah yaitu Shalat, Puasa, dan membaca al-qur'an serta Ibadah ghairu mahdah yaitu, bershadaqah, menebarkan salam dan ganjaran; serta Nilai Pendidikan Akhlak, yang meliputi akhlak kepada allah yaitu beriman dan

\footnotetext{
${ }^{35}$ Ibid., hlm. 10 .
} 
bertaqwa, dan istiqamah. Kemudian akhlak terhadap diri sendiri yang meliputi sabar, menunaikan amanah, benar dan jujur, dan menepati janji. Dan akhlak kepada keluarga yang meliputi berbakti kepada kedua orang tua dan bersikap baik kepada saudara.[]

\section{DAFTAR PUSTAKA}

Aisah, 'Nilai-Nilai Pendidikan Islam Dalam Novel Isra' Mi'raj Cinta Karya Rohmat Nurhadi AlKastani”, Skripsi, Bogor: STIT Sirojul Falah, 2017

Amraini, https://amraini.com/tafsir-surah-adz-dzariyat-ayat-56-qs-5156/, (Diakses pada 22 Februari 2020, jam 14:50)

Anggareni, Dewi dan Siti Suhartinah, "Toleransi Antar Umat Beragama Perspektif KH. Ali Mustafa Yaqub” Jurnal Studi Al-Qur'an, Vol.14, No. 1, April 2018

B.A , Abu H.F. Ramadhan "Fathul Qarib Pengantar Fiqih Imam Syafi'I”, Terj.Syekh Syamsuddin Abu Abdillah, Surabaya: Mutiara Ilmu, 2010.

Iwan, "Pendidikan Akhlak Terpuji Mempersiapkan Generasi Muda Berkarakter", Jurnal A1 Tarbawi Al Haditsah, Vol.1, No.1

Majid , Abdul Aziz Abdul , mendidik Dengan Cerita, Bandung: Remaja Rosdakarya, 2013

Muzaki, Jajang Aisyul "Pemikiran Al-Ghazali Tentang Ganjaran dan Hukuman Dalam Pendidikan Anak", Jurnal Pendidikan Anak, Vol.3, No.1, Februari 2017.

Nasution ,Syahrudin dan Khoirudin Nasution, “Mengkaji Nilai Salam Dalam Al-Qur'an (Kajian Tafsir Tematik)", Jurnal Ushuludin, Vol.25, No.1, Januari - Juni 2017.

Rosyadi, Rahmat "Pendidikan Islam Dalam Perspektif Kebijakan Pendidikan Nasional", Bogor: PT Penerbit IPB Press, 2004

Saputro,Eko, "Penanaman Nilai-Nilai Pendidikan Agama Islam melalui Kegiatan Cinta Alam” Mudarissa, Vol.7, No. 1, Juni 2015

Sudarsono, "Pendidikan Ibadah Perspektif Al-Qur'an Dan Hadits", Cendekia, Vol.4, No.1, Juni 2018.

Supriyatin, Akhlak Tasawuf, Tasik Malaya: Latifah Pers, 2016.

Uyyun, Qurratul, "Zakat, Infaq,Shadaqah dan Wakaf Sebagai Konfigurasi Filantropi Islam", Islamuna, Vol.2, No. 2, Desember 2015.

Yusuf, Ahmad Muhammad, “ Ensiklopedia Tematis Ayat Al-Qur'an dan Hadits, Jakarta: Widya Cahaya, 2009.

Zakiyah, Qiqi Yuliati dan A.Rusdiana, "Pendidikan Nilai", Bandung: CV. Pustaka Setia,2014 